\title{
Adana İli Seyhan İlçesindeki Su Depolarının Bakteriyolojik ve Fizikokimyasal Açıdan İncelenmesi
}

\author{
Rozelin AYDIN"1, Yağmur ATAKAV ${ }^{1}$ \\ ${ }^{1}$ Adana Bilim ve Teknoloji Üniversitesi, Mühendislik Fakültesi, Biyomühendislik Bölümü, \\ Adana
}

Geliş tarihi: 09.10.2017

Kabul tarihi: 14.03 .2018

\section{$\ddot{\mathbf{O} z}$}

$\mathrm{Bu}$ çalışma, Adana'nın Seyhan ilçesindeki apartmanlardaki su depolarının fizikokimyasal ve mikrobiyolojik kalitesinin belirlenmesi amacıyla yapılmıştır. Bu amaç doğrultusunda 53 apartmandan depo giriş, depo çıkış ve 1 . kat olmak üzere toplamda 159 adet su numunesi toplandı. Su numunelerinde fizikokimyasal özelliklerden tat, koku, bulanıklılık, toplam sertlik, $\mathrm{pH}$ ve bakiye klor ölçümü yapılırken, mikrobiyolojik olarak $37{ }^{\circ} \mathrm{C}$ 'de koloni sayımı, Enterekok, E. coli, total koliform bakterilerin varlığ araştırıldı. Depo girişinden, yani şebekeden alınmış olan su örneklerinde $\% 0,63$ oranında total koloni sayımında, $\% 1,89$ oranında ise total koliform bakteri, $\% 0 \mathrm{E}$. coli uygunsuzluğuna rastlanmıştır. Çıkış sularında ise $\% 0,63$ enterekok, $\% 14,5$ total koloni sayımı, $\% 5$ total koliform ve $\% 0$ E. coli bakteri tespit edilmiştir. Saha da yapılan ölçümlerde bakiye klor sadece 4 apartmanın su deposunda ölçülebilmiş̧ir. Su numunelerinin geneli orta sertlikte olduğu gözlemlenmiştir. Alınan su numunelerinde 2 istisnai örnek dışında renk, tat, bulanıklılık ve koku problemi de bulunmamaktadır. Örneklerin $\mathrm{pH}$ düzeyleri incelendiğinde şebeke suyunun 6,9-8,4 değerleri arasında ve ortalama 7,4 değerinde olduğu ölçülmüştür. Yapılan çalışma sonunda, suyun bina içi su yapılarına kadar temiz bir şekilde ulaştığı varsayılsa bile suların depolandığı su depolarının çok kritik bir öneme sahip olduğu görülmüştür.

Anahtar Kelimeler: Su depoları, bakteriyolojik ve fizikokimyasal kirlilik, Enterekok, E. coli, total koliform

\section{Bacteriological and Physicochemical Investigation of Residential Water Storage Tanks in the District of Seyhan, Adana Province}

\begin{abstract}
This study was carried out in order to determine the physicochemical and microbiological quality of the water storage tanks located in the apartment buildings in the Seyhan district of Adana. For this purpose, a total of 159 water samples were collected from 53 apartment, including the inlet, outlet of water storage tank and from the first floor. Colonic counts at $37{ }^{\circ} \mathrm{C}$, Enterecocci, E. coli, total coliform bacteria were investigated for microbiological analysis, while taste, odor, turbidity, total hardness, $\mathrm{pH}$ and residual chlorine were measured for physicochemical properties in water samples. The samples that were taken
\end{abstract}

*Sorumlu yazar (Corresponding author): Rozelin AYDIN, raydin@adanabtu.edu.tr 
from the inlet of the tanks showed $0,63 \%$ total coliform bacteria, $1,89 \%$ total colonic counts, $0 \%$ E. coli. The outlet sample analysis indicated $0,63 \%$ Enterecocci, 14,5\% total colonic counts, 5\% total coliform bacteria and $0 \%$ E.coli. In the field measurements, the residual chlorine was only measured for 4 apartments. It had been observed that the water samples were of the medium moderate hardness. Also, no color, taste, turbidity or odor problems were observed in the samples except for 2 water samples. When the $\mathrm{pH}$ levels of the samples were examined, it was measured that the $\mathrm{pH}$ of the tap water had values varying between 6.9-8.4 and an average value of 7.4. As a result of our study, it was seen that even if the water reaches in a clean condition up to the in-building water structures, the tanks that the water is kept play an important role in the sanitation of the water.

Keywords: Water storage tanks, bacteriological and physicochemical pollution, enterecocci, E. coli, total coliform

\section{GíRiș}

En küçük canlı organizmadan, en büyük canlı varlığa kadar, bütün biyolojik hayatı ve bütün insan faaliyetlerini ayakta tutan sudur. Suyun yaşamsal önemi günümüzde, sosyal, çevresel, stratejik ve ekonomik boyutlariyla ele alınmaktadır. Nüfusun hızla artması, buna karşılık su kaynaklarının sabit kalması sebebiyle su ihtiyacı her geçen gün artmaktadır. Buna ek olarak, 2050 yılında su sıkıntısı çeken ülkelerin sayısı 54'e ulaşırken, bu şartlarda yaşamak zorunda kalan insanların sayısı 3,76 milyara ulaşacaktır. $\mathrm{Bu}$ durum 2050 de 9,4 milyar olması beklenen dünya nüfusunun \%40'ının su sıkıntısı çekeceği anlamına gelmektedir $[1,2]$.

Günümüzde teknoloji ve sağlık alanındaki ilerlemelere rağmen, halen insan sağlığını ve yaşamını tehdit eden tehlikelerin en başında hastalık yapıcı mikroorganizmalar yer almaktadır. Sağlıklı bir su, içerisinde hastalık yapan mikroorganizmaları ve toksik kimyasalları içermeyen ve gerekli minaralleri bünyesinde bulundurabilen sudur $[1,3]$.

Su, doğrudan hastalık nedeni olabileceği gibi, hastalıklar için zemin hazırlayabilmekte ya da bazı hastalıkların oluşmasını kolaylaştırabilmektedir. Bu nedenle, insan sağlığının korunmasında sağlıklı ve güvenli suya erişim büyük önem taşımaktadır.

Sağlıklı bir içme suyu erişiminin sağlanamadığı koşullarda, içme sularında kolera (Vibrio cholerae), tifo ve/veya paratifo (Salmonella Typhi ve S. Paratyphi), sulu ishal (Escherichia coli), basiller dizanteri (Shigella dysenteriae), kriptosporidiozis (Criptosporidium), giardiazis (Giardia lamblia), hepatit A ve E, Dengue hummas1, Legionella enfeksiyonu, Leptospira enfeksiyonu, Mantar hastalıkları, Norwalk ve benzeri virüs enfeksiyonu, Siyanobakteri toksikozlarının görülme sıklığı da artmaktadır $[4,5]$. Yapılan istatistikler göstermektedir ki dünyada tüm hastalıkların hemen hemen yarıya yakını sularla birebir ilişkilidir. Dünyadaki ishal vakalarının \%88'i güvenli olmayan su kullanımı ile sanitasyon ve hijyendeki eksikliklere bağlıdır. Sularla bulaşan enfeksiyöz ishaller, ölüm nedenleri içinde halen 2. sırada yer almaktadır. Dünya Sağlık Örgütü'ne göre 0-14 yaş arasındaki çocuk ölümlerinin \%18'inin (2,2 milyon çocuk) su ve sanitasyonla ilişkili olduğu ve dolayısıyla önlenebilir olduğu tahmin edilmektedir. Ulusal Hastalık Yükü Çalışması'na göre Türkiye'de de 014 yaş grubunda ölüm nedenleri sıralamasında ishalli hastalıklar \%8,4 ile 4. sirada yer almaktadır. İshalli hastalıkların 0-14 yaş grubunda ölüm nedenleri arasındaki payı kentsel alanda \%6,2, kırsal alanda \%9,8 olarak kendini göstermektedir.

$\mathrm{Bu}$ sorunları ve olumsuzlukları engellemek kullanılabilir su kalitesini artırmak ve sağlık şartlarının iyileştirilmesi ile mümkün olacaktır.

Türkiye Nüfus ve Sağlık Araştırması-2008 (TNSA-2008) verilerine göre Türkiye'de hanelerin \%92'si (kent-kır sirasıyla \%94-\%88) 
iyileştirilmiş su kaynağına (şebeke suyu, kuyu suyu, şebekeyle pınar suyu ve şişe suyu) erişebilmektedir. Türkiye Sağlıklı Kentler Birliği Strateji Planı 2005-2020'de, TÜIKK verilerine göre 2002 y1linda $\% 75$ olan yeterli ve kaliteli suya ulaşan nüfus oranının, 2020 yılında $\% 98$ 'e ulaşmasının hedeflendiği belirtilmektedir. [3rapor].

Ülkemizde sağlıklı ve güvenli içme-kullanma suyunun topluma ulaştırılması yerel yönetimlerin, bu suyun kalitesinin izlenmesi ise Sağlık Bakanlığı'nın görevidir. İçme-kullanma sularının kalite standartları, $\mathrm{AB}$ direktifi doğrultusunda suyun kalite standartlarını belirlemek üzere hazırlanmış ve 17/2/2005 tarihinde yürürlüğe girmiş olan "İnsani Tüketim Amaçlı Sular Hakkında Yönetmelik”te belirlenmiștir. Bu yönetmeliğe göre içme ve kullanma sularında, denetim ve kontrol izlemesi olarak tanımlanmış iki farklı tür izleme yapılmaktadır. Her iki izlemede de fiziksel, kimyasal ve mikrobiyolojik parametreler yer almaktadır.

İnsani amaçlı kullanılan suların depolara kadar güvenli ve sağlıklı bir şekilde getirilse bile kullanım amaçlı suların sadece depoya koyularak muhafaza edilmesi asla yeterli değildir. Bu nedenle su depolarının temiz, güvenli ve sağlıklı koşullarda olmasına dikkat edilmesi ve belli aralıklarda temizlenmesi gerekmektedir. Ayrıca içme suyu depolarında kullanılan malzemelerin mikrobiyolojik gelişmeye yer vermeyecek malzemelerden yapılması da büyük önem arz etmektedir [6].

Çalışmamızın amacı Adana İli Seyhan İlçesi'ndeki apartmanlardaki farklı tipteki su depolarının mikrobiyolojik ve fizikokimyasal durumlarının incelenmesini kapsamaktadır.

\section{MATERYAL VE METOT}

Anket çalışmamız [7] sonucunda ulaşılan 53 apartmanın depo giriş depo çıkış ve apartmanların birinci katlarından farklı niteliklerdeki depolardan (beton, fayans, galvaniz, krom ve plastik) 17/2/2005 tarihinde yürürlüğe girmiş olan "İnsani
Tüketim Amaçlı Sular Hakkında Yönetmelik”te belirtilen şekilde 159 adet su numunesi alınmıştır. Alınan su numuneleri fizikokimyasal ve bakteriyolojik açıdan incelemeye tabi tutulmuştur. Fizikokimyasal özelliklerden tat, renk, koku, bulanıklık, $\mathrm{pH}$, sicaklık, iletkenlik, toplam sertlik ve bakiye klor değerlerine sahada bakılmış ve yönetmeliğe göre analiz sonuçları değerlendirilmişstir.

Alınan su numunelerinin bakteriyolojik analizleri için İnsani Amaçlı Sular Hakkındaki Yönetmelikte $(17.02 .2005 / 25730) \quad$ belirtilen şekilde su numuneleri özel numune alma kapları yardımıyla alınarak soğuk zincirle aynı gün içerisinde içmekullanma sularının analizinde tek yetkili ve akredite kurum olan Adana Halk Sağlığ Laboratuvarı'na götürülerek yönetmelikte istenen şartlara göre analizleri yapılmıştır. Bakteriyolojik analizler kapsaminda Enterekok, Koliform, Escherichia coli varlığ 1 ve $37^{\circ} \mathrm{C}$ 'de koloni sayımı parametrelerine bakılmıştır.

Escherichia coli ve Koliform bakteri analizleri TS EN ISO 9308-1 metoduna göre analiz edilmiştir. $\mathrm{Bu}$ standartta önerilen analiz yöntemi, membran filtrasyon işlemi sonrasında selektif bir besiyerine ekim ve numunedeki hedef mikroorganizmaların sayımına dayanmaktadır. Numunelerin her birinden iki tekrarlı çalışılmış ve $100 \mathrm{~mL}$ 'lik örnekler alınarak $0,45 \mu \mathrm{m}$ por çaplı steril membran filtreden süzülmüş ve CCA (Kromojenik) Agar (Merck) besiyerine yerleştirilmiş̧ir. Besiyeri $36 \pm 2^{\circ} \mathrm{C}^{\prime}$ de 24 saat inkübe edilmiştir. 24 saat sonunda plaklarda görülen mor renkli koloniler $E$. coli olarak kabul edilmiştir. Pembe renkli koloniler oksidaz (Merck) ile doğrulama yapılmıştır. Bu iki farklı renkteki kolonilerin toplamı total koliform bakteri sayısını vermiştir. Enterekok ise TS EN ISO 7899-2 metoduna göre Adana Halk Sağlı̆̆ Laboratuvar'ında çalışılmıştır. Her bir numunenin analizi için, $100 \mathrm{~mL}$ su $0,45 \mu \mathrm{m}$ por çaplı membran filtreden süzülmüş ve filtre Slanetz-Bartley besiyerine (Merck) konulmuştur. Besiyeri $36 \pm 1{ }^{\circ} \mathrm{C}$ 'de 48 saat inkübe edilmiş ve besiyerinde gelişen şüpheli koloniler safra eskülin azid agar besiyeri (Merck) kullanılarak doğruluğu 
test edilmiştir. $37^{\circ} \mathrm{C}$ 'de koloni sayımı TS EN ISO 6222 metoduna göre Adana Halk Sağlığ Laboratuvarı'nda yapılmıștır. Buna göre numuneler genel üretici besi yeri kullanılarak (Plate Count Agar) ekime alınmış ve $36 \pm 2{ }^{\circ} \mathrm{C}$ 'ta $44 \pm 4$ saat inkübe edilmiştir. İnkübasyon sonrasında her $1 \mathrm{~mL}$ numune için besiyerinde oluşan her çeşit koloni sayılmıştır.

\section{BULGULAR}

Depoların cinsine göre alınan örnekler sırasıyla; 15 Beton, 12 Fayans, 13 Galvaniz, 12 Krom, 1 Plastik depodan oluşmaktadır (Çizelge 1 ve 2).

\subsection{Fizikokimyasal Bulgular}

Alınan su numunelerinin hem giriş suyu örneklerinde, hem çıkış suyunda hem de 1. kattan alınan örneklerde tat, renk, koku ve bulanıklık analiz sonuçları İnsani Tüketim Amaçlı Sular Hakkındaki (17 Şubat 2005/25730-Avrupa Birliğine Üye Ülkelerce esas alınan İnsani Kullanım Amaçlı Suların Kalitesine Dair 98/83/EC sayılı Konsey Direktifi, Doğal Mineralli Suların Çıkartılması ve Pazarlanmasına İlişkin Üye Devletlerin Kanunlarının Uyumlaştırılması Hakkındaki 15/7/1980 tarihli ve 80/777/EEC say1lı
Konsey Direktifi ile Doğal Mineralli Sular İçin Konsantrasyon Limitleri ve Etiketleme Bilgileri Hakkında Liste Oluşturulması ve Doğal Mineralli Suların ve Kaynak Sularının Ozonla Zenginleştirilmiş̧ Hava ile İşleme Tabi Tutulmasının Şartlarını Belirleyen 16/5/2003 tarihli ve 2003/40/EC sayll Konsey Direktifine paralel olarak çıarılmıs yönetmelik) yönetmelikte belirtilen limitler içerisinde bulunmuştur (Çizelge 1).

Saha da yapılan bakiye klor ölçümünde yalnızca 4 apartmanda değer alınabilmiştir. Normal şartlarda şebeke sularındaki serbest klor miktarı 0,5 ppm (mg/L) olması beklenmektedir. Bu da bizlere klorlamanın yeterli sıklıkta yapılmadığ göstermektedir.

Ülkemizde yaygın olarak toplam sertlik değerlendirilirken Fransız sertliği (Fr) veya mg/lt $\mathrm{CaCO}_{3}$ sertlik siniflandirmasinda kullanılan birimlerdir. 1 Fr derecesi $10 \quad \mathrm{mg} / \mathrm{lt} \quad \mathrm{CaCO}_{3}$ sertliğine eşittir. İncelenen örneklerinin toplam sertliklerinin 19-21,5 Fransız sertlik derecesi aralığında ortalama 20,41 Fransız sertliği derecesine sahip olduğu ölçülmüştür. Yani su numunelerinin geneli orta sertliktedir.

Çizelge 1. Fizikokimyasal analiz sonuçları

\begin{tabular}{|c|c|c|c|c|c|c|c|c|c|}
\hline $\begin{array}{c}\text { Apartman } \\
\text { Sayısı }\end{array}$ & $\begin{array}{c}\text { Örnek } \\
\text { Yeri }\end{array}$ & Depo Tipi & Tat & Koku & Bulanıklık & Renk & pH & Alkalinite & Klor \\
\hline \multirow{3}{*}{1} & Giriş & \multirow{3}{*}{ Beton } & Uygun* & Uygun & Uygun & Uygun & 7,1 & 210 & 0 \\
\hline & Ç1k1ş & & Uygun & Uygun & Uygun & Uygun & 7,1 & 210 & 0 \\
\hline & 1. Kat & & Uygun & Uygun & Uygun & Uygun & 7,1 & 210 & 0 \\
\hline \multirow{3}{*}{2} & Giriş & \multirow{3}{*}{ Beton } & Uygun & Uygun & Uygun & Uygun & 7,4 & 180 & 0 \\
\hline & Ç1k1ş & & Uygun & Uygun & Uygun & Uygun & 7,4 & 180 & 0 \\
\hline & 1. Kat & & Uygun & Uygun & Uygun & Uygun & 7,4 & 180 & 0 \\
\hline \multirow{3}{*}{3} & Giriş & \multirow{3}{*}{ Beton } & Uygun & Uygun & Uygun & Uygun & 7,4 & 220 & 0 \\
\hline & Ç1k1ş & & Uygun & Uygun & Uygun & Uygun & 7,4 & 220 & 0 \\
\hline & 1. Kat & & Uygun & Uygun & Uygun & Uygun & 7,4 & 220 & 0 \\
\hline \multirow{3}{*}{4} & Giriş & \multirow{3}{*}{ Fayans } & Uygun & Uygun & Uygun & Uygun & 7,3 & 210 & 0 \\
\hline & Çıkış & & Uygun & Uygun & Uygun & Uygun & 7,3 & 210 & 0 \\
\hline & 1. Kat & & Uygun & Uygun & Uygun & Uygun & 7,3 & 210 & 0 \\
\hline \multirow{3}{*}{5} & Giriş & \multirow{3}{*}{ Galvaniz } & Uygun & Uygun & Uygun & Uygun & 7,2 & 190 & 0 \\
\hline & Ç1kış & & Uygun & Uygun & Uygun & Uygun & 7,2 & 190 & 0 \\
\hline & 1. Kat & & Uygun & Uygun & Uygun & Uygun & 7,2 & 190 & 0 \\
\hline
\end{tabular}




\begin{tabular}{|c|c|c|c|c|c|c|c|c|c|}
\hline \multirow{3}{*}{6} & Giriş & \multirow{3}{*}{ Galvaniz } & Uygun & Uygun & Uygun & Uygun & 7,1 & 200 & 0 \\
\hline & Çıkış & & Uygun & Uygun & Uygun & Uygun & 7,1 & 200 & 0 \\
\hline & 1. Kat & & Uygun & Uygun & Uygun & Uygun & 7,1 & 200 & 0 \\
\hline \multirow{3}{*}{7} & Giriş & \multirow{3}{*}{ Galvaniz } & Uygun & Uygun & Uygun & Uygun & 7,1 & 170 & 0 \\
\hline & Çıkış & & Uygun & Uygun & Uygun & Uygun & 7,1 & 170 & 0 \\
\hline & 1. Kat & & Uygun & Uygun & Uygun & Uygun & 7,1 & 170 & 0 \\
\hline \multirow{3}{*}{8} & Giriş & \multirow{3}{*}{ Galvaniz } & Uygun & Uygun & Uygun & Uygun & 7,3 & 220 & 0 \\
\hline & Çıkış & & Uygun & Uygun & Uygun & Uygun & 7,3 & 220 & 0 \\
\hline & 1. Kat & & Uygun & Uygun & Uygun & Uygun & 7,3 & 220 & 0 \\
\hline \multirow{3}{*}{9} & Giriş & \multirow{3}{*}{ Krom } & Uygun & Uygun & Uygun & Uygun & 7,6 & 200 & 0 \\
\hline & Çıkısş & & Uygun & Uygun & Uygun & Uygun & 7,6 & 200 & 0 \\
\hline & 1. Kat & & Uygun & Uygun & Uygun & Uygun & 7,6 & 200 & 0 \\
\hline \multirow{3}{*}{10} & Giriş & \multirow{3}{*}{ Galvaniz } & Uygun & Uygun & Uygun & Uygun & 7,4 & 180 & 0 \\
\hline & Çıkış & & Uygun & Uygun & Uygun & Uygun & 7,4 & 180 & 0 \\
\hline & 1. Kat & & Uygun & Uygun & Uygun & Uygun & 7,4 & 180 & 0 \\
\hline \multirow{3}{*}{11} & Giriş & \multirow{3}{*}{ Plastik } & Uygun & Uygun & Uygun & Uygun & 7,2 & 210 & 0 \\
\hline & Çıkış & & Uygun & Uygun & Uygun & Uygun & 7,2 & 210 & 0 \\
\hline & 1. Kat & & Uygun & Uygun & Uygun & Uygun & 7,2 & 210 & 0 \\
\hline \multirow{3}{*}{12} & Giriş & \multirow{3}{*}{ Krom } & Uygun & Uygun & Uygun & Uygun & 7,4 & 180 & 0 \\
\hline & Çıkış & & Uygun & Uygun & Uygun & Uygun & 7,4 & 180 & 0 \\
\hline & 1. Kat & & Uygun & Uygun & Uygun & Uygun & 7,4 & 180 & 0 \\
\hline \multirow{3}{*}{13} & Giriş & \multirow{3}{*}{ Fayans } & Uygun & Uygun & Uygun & Uygun & 7,3 & 210 & 0 \\
\hline & Çıkış̧ & & Uygun & Uygun & Uygun & Uygun & 7,3 & 210 & 0 \\
\hline & 1. Kat & & Uygun & Uygun & Uygun & Uygun & 7,3 & 210 & 0 \\
\hline \multirow{3}{*}{14} & Giriş & \multirow{3}{*}{ Galvaniz } & Uygun & Uygun & Uygun & Uygun & 7,4 & 200 & 0 \\
\hline & Çıkış & & Uygun & Uygun & Uygun & Uygun & 7,4 & 200 & 0 \\
\hline & 1. Kat & & Uygun & Uygun & Uygun & Uygun & 7,4 & 200 & 0 \\
\hline \multirow{3}{*}{15} & Giriş & & Uygun & Uygun & Uygun & Uygun & 6,9 & 160 & 0 \\
\hline & Çıkış & Krom & Uygun & Uygun & Uygun & Uygun & 6,9 & 160 & 0 \\
\hline & 1. Kat & & Uygun & Uygun & Uygun & Uygun & 6,9 & 160 & 0 \\
\hline & Giriş & & Uygun & Uygun & Uygun & Uygun & 7,4 & 210 & 0 \\
\hline 16 & Çıkış & Beton & Uygun & Uygun & Uygun & Uygun & 7,4 & 210 & 0 \\
\hline & 1. Kat & & Uygun & Uygun & Uygun & Uygun & 7,4 & 210 & 0 \\
\hline & Giriş & & Uygun & Uygun & Uygun & Uygun & 7,4 & 200 & 0 \\
\hline 17 & Çıkış & Krom & Uygun & Uygun & Uygun & Uygun & 7,4 & 200 & 0 \\
\hline & 1. Kat & & Uygun & Uygun & Uygun & Uygun & 7,4 & 200 & 0 \\
\hline & Giriş & & Uygun & Uygun & Uygun & Uygun & 7,5 & 210 & 0 \\
\hline 18 & Çıkış & Fayans & Uygun & Uygun & Uygun & Uygun & 7,5 & 210 & 0 \\
\hline & 1. Kat & & Uygun & Uygun & Uygun & Uygun & 7,5 & 210 & 0 \\
\hline & Giriş & & Uygun & Uygun & Uygun & Uygun & 7,5 & 200 & 1,1 \\
\hline 19 & Çıkış & Galvaniz & Uygun & Uygun & Uygun & Uygun & 7,5 & 200 & 1,1 \\
\hline & 1. Kat & & Uygun & Uygun & Uygun & Uygun & 7,5 & 200 & 1,1 \\
\hline & Giriş & & Uygun & Uygun & Uygun & Uygun & 7,4 & 210 & 0 \\
\hline 20 & Çıkış & Galvaniz & Uygun & Uygun & Uygun & Uygun & 7,4 & 210 & 0 \\
\hline & 1. Kat & & Uygun & Uygun & Uygun & Uygun & 7,4 & 210 & 0 \\
\hline & Giriş & & Uygun & Uygun & Uygun & Uygun & 8,4 & 200 & 6 \\
\hline 21 & Ç1k1ş & Fayans & Uygun & Uygun & Uygun & Uygun & 8,4 & 200 & 6 \\
\hline & 1. Kat & & Uygun & Uygun & Uygun & Uygun & 8,4 & 200 & 6 \\
\hline & Giriş & & Uygun & Uygun & Uygun & Uygun & 8,2 & 160 & 0 \\
\hline 22 & Çıkış & Fayans & Uygun & Uygun & Uygun & Uygun & 8,2 & 160 & 0 \\
\hline & 1. Kat & & Uygun & Uygun & Uygun & Uygun & 8,2 & 160 & 0 \\
\hline
\end{tabular}


Adana İli Seyhan İlçesindeki Su Depolarının Bakteriyolojik ve Fizikokimyasal Açıdan İncelenmesi

\begin{tabular}{|c|c|c|c|c|c|c|c|c|c|}
\hline \multirow{3}{*}{23} & Giriş & \multirow{3}{*}{ Beton } & Uygun & Uygun & Uygun & Uygun & 7,6 & 240 & 9,9 \\
\hline & Çıkış & & Uygun & Uygun & Uygun & Uygun & 7,6 & 240 & 9,9 \\
\hline & 1. Kat & & Uygun & Uygun & Uygun & Uygun & 7,6 & 240 & 9,9 \\
\hline \multirow{3}{*}{24} & Giriş & \multirow{3}{*}{ Beton } & Uygun & Uygun & Uygun & Uygun & 7,3 & 210 & 0 \\
\hline & Çıkış & & Uygun & Uygun & Uygun & Uygun & 7,3 & 210 & 0 \\
\hline & 1. Kat & & Uygun & Uygun & Uygun & Uygun & 7,3 & 210 & 0 \\
\hline \multirow{3}{*}{25} & Giriş & \multirow{3}{*}{ Beton } & Uygun & Uygun & Uygun & Uygun & 7,4 & 190 & 0 \\
\hline & Ç1kış & & Uygun & Uygun & Uygun & Uygun & 7,4 & 190 & 0 \\
\hline & 1.Kat & & Uygun & Uygun & Uygun & Uygun & 7,4 & 190 & 0 \\
\hline \multirow{3}{*}{26} & Giriş & \multirow{3}{*}{ Beton } & Uygun & Uygun & Uygun & Uygun & 7,4 & 200 & 0 \\
\hline & Çıkısş & & Uygun & Uygun & Uygun & Uygun & 7,4 & 200 & 0 \\
\hline & 1. Kat & & Uygun & Uygun & Uygun & Uygun & 7,4 & 200 & 0 \\
\hline \multirow{3}{*}{27} & Giriş & \multirow{3}{*}{ Beton } & Uygun & Uygun & Uygun & Uygun & 7,6 & 180 & 0 \\
\hline & Çıkış & & Uygun & Uygun & Uygun & Uygun & 7,6 & 180 & 0 \\
\hline & 1. Kat & & Uygun & Uygun & Uygun & Uygun & 7,6 & 180 & 0 \\
\hline \multirow{3}{*}{28} & Giriş & \multirow{3}{*}{ Galvaniz } & Uygun & Uygun & Uygun & Uygun & 7,5 & 210 & 0 \\
\hline & Çıkış & & Uygun & Uygun & Uygun & Uygun & 7,5 & 210 & 0 \\
\hline & 1. Kat & & Uygun & Uygun & Uygun & Uygun & 7,5 & 210 & 0 \\
\hline \multirow{3}{*}{29} & Giriş & \multirow{3}{*}{ Fayans } & Uygun & Uygun & Uygun & Uygun & 7,4 & 220 & 0 \\
\hline & Çıkış & & Uygun & Uygun & Uygun & Uygun & 7,4 & 220 & 0 \\
\hline & 1. Kat & & Uygun & Uygun & Uygun & Uygun & 7,4 & 220 & 0 \\
\hline \multirow{3}{*}{30} & Giriş & \multirow{3}{*}{ Fayans } & Uygun & Uygun & Uygun & Uygun & 7,5 & 200 & 0 \\
\hline & Çıkıış & & Uygun & Uygun & Uygun & Uygun & 7,5 & 200 & 0 \\
\hline & 1. Kat & & Uygun & Uygun & Uygun & Uygun & 7,5 & 200 & 0 \\
\hline \multirow{3}{*}{31} & Giriş & \multirow{3}{*}{ Beton } & Uygun & Uygun & Uygun & Uygun & 7,5 & 240 & 0 \\
\hline & Çıkıș & & Uygun & Uygun & Uygun & Uygun & 7,5 & 240 & 0 \\
\hline & 1. Kat & & Uygun & Uygun & Uygun & Uygun & 7,5 & 240 & 0 \\
\hline \multirow{3}{*}{32} & Giriş & & Uygun & Uygun & Uygun & Uygun & 7,1 & 190 & 0 \\
\hline & Çıkış & Galvaniz & Uygun & Uygun & Uygun & Uygun & 7,1 & 190 & 0 \\
\hline & 1. Kat & & Uygun & Uygun & Uygun & Uygun & 7,1 & 190 & 0 \\
\hline & Giriş & & Uygun & Uygun & Uygun & Uygun & 7,5 & 220 & 0 \\
\hline 33 & Çıkış & Krom & Uygun & Uygun & Uygun & Uygun & 7,5 & 220 & 0 \\
\hline & 1. Kat & & Uygun & Uygun & Uygun & Uygun & 7,5 & 220 & 0 \\
\hline & Giriş & & Uygun & Uygun & Uygun & Uygun & 7,2 & 200 & 0 \\
\hline 34 & Çıkış & Beton & Uygun & Uygun & Uygun & Uygun & 7,2 & 200 & 0 \\
\hline & 1. Kat & & Uygun & Uygun & Uygun & Uygun & 7,2 & 200 & 0 \\
\hline & Giriş & & Uygun & Uygun & Uygun & Uygun & 7,4 & 220 & 0 \\
\hline 35 & Çıkış & Beton & Uygun & Uygun & Uygun & Uygun & 7,4 & 220 & 0 \\
\hline & 1. Kat & & Uygun & Uygun & Uygun & Uygun & 7,4 & 220 & 0 \\
\hline & Giriş & & Uygun & Uygun & Uygun & Uygun & 6,9 & 210 & 0 \\
\hline 36 & Çıkış & Galvaniz & Uygun & Uygun & Uygun & Uygun & 6,9 & 210 & 0 \\
\hline & 1. Kat & & Uygun & Uygun & Uygun & Uygun & 6,9 & 210 & 0 \\
\hline & Giriş & & Uygun & Uygun & Uygun & Uygun & 7,1 & 200 & 0 \\
\hline 37 & Çıkış & Krom & Uygun & Uygun & Uygun & Uygun & 7,1 & 200 & 0 \\
\hline & 1. Kat & & Uygun & Uygun & Uygun & Uygun & 7,1 & 200 & 0 \\
\hline & Giriş & & Uygun & Uygun & Uygun & Uygun & 7,5 & 220 & 0 \\
\hline 38 & Çı1kış & Galvaniz & Uygun & Uygun & Uygun & Uygun & 7,5 & 220 & 0 \\
\hline & 1. Kat & & Uygun & Uygun & Uygun & Uygun & 7,5 & 220 & 0 \\
\hline & Giriş & & Uygun & Uygun & Uygun & Uygun & 7,3 & 210 & 0 \\
\hline 39 & Çıkış & Krom & Uygun & Uygun & Uygun & Uygun & 7,3 & 210 & 0 \\
\hline & 1. Kat & & Uygun & Uygun & Uygun & Uygun & 7,3 & 210 & 0 \\
\hline
\end{tabular}




\begin{tabular}{|c|c|c|c|c|c|c|c|c|c|}
\hline \multirow{3}{*}{40} & Giriş & \multirow{3}{*}{ Krom } & Uygun & Uygun & Uygun & Uygun & 7,2 & 240 & 0 \\
\hline & Çıkış & & Uygun & Uygun & Uygun & Uygun & 7,2 & 240 & 0 \\
\hline & 1. Kat & & Uygun & Uygun & Uygun & Uygun & 7,2 & 240 & 0 \\
\hline \multirow{3}{*}{41} & Giriş & \multirow{3}{*}{ Galvaniz } & Uygun & Uygun & Uygun & Uygun & 7,1 & 200 & 0 \\
\hline & Çıkış & & Uygun & Uygun & Uygun & Uygun & 7,1 & 200 & 0 \\
\hline & 1. Kat & & Uygun & Uygun & Uygun & Uygun & 7,1 & 200 & 0 \\
\hline \multirow{3}{*}{42} & Giriş & \multirow{3}{*}{ Beton } & Uygun & Uygun & Uygun & Uygun & 6,9 & 180 & 0 \\
\hline & Çıkış & & Uygun & Uygun & Uygun & Uygun & 6,9 & 180 & 0 \\
\hline & 1. Kat & & Uygun & Uygun & Uygun & Uygun & 6,9 & 180 & 0 \\
\hline \multirow{3}{*}{43} & Giriş & \multirow{3}{*}{ Fayans } & Uygun & Uygun & Uygun & Uygun & 7,3 & 200 & 0 \\
\hline & Çıkış & & Uygun & Uygun & Uygun & Uygun & 7,3 & 200 & 0 \\
\hline & 1. Kat & & Uygun & Uygun & Uygun & Uygun & 7,3 & 200 & 0 \\
\hline \multirow{3}{*}{44} & Giriş & \multirow{3}{*}{ Krom } & Uygun & Uygun & Uygun & Uygun & 7,4 & 180 & 0 \\
\hline & Çıkış & & Uygun & Uygun & Uygun & Uygun & 7,4 & 180 & 0 \\
\hline & 1. Kat & & Uygun & Uygun & Uygun & Uygun & 7,4 & 180 & 0 \\
\hline \multirow{3}{*}{45} & Giriş & \multirow{3}{*}{ Fayans } & Uygun & Uygun & Uygun & Uygun & 7,5 & 190 & 0 \\
\hline & Çıkış & & Uygun & Uygun & Uygun & Uygun & 7,5 & 190 & 0 \\
\hline & 1. Kat & & Uygun & Uygun & Uygun & Uygun & 7,5 & 190 & 0 \\
\hline \multirow{3}{*}{46} & Giriş & \multirow{3}{*}{ Fayans } & Uygun & Uygun & Uygun & Uygun & 7,2 & 210 & 0 \\
\hline & Çıkış & & Uygun & Uygun & Uygun & Uygun & 7,2 & 210 & 0 \\
\hline & 1. Kat & & Uygun & Uygun & Uygun & Uygun & 7,2 & 210 & 0 \\
\hline \multirow{3}{*}{47} & Giriş & \multirow{3}{*}{ Saç Depo } & Uygun & Uygun & Uygun & Uygun & 7,3 & 210 & 0 \\
\hline & Çıkış & & Uygun & Uygun & Uygun & Uygun & 7,3 & 210 & 0 \\
\hline & 1. Kat & & Uygun & Uygun & Uygun & Uygun & 7,3 & 210 & 0 \\
\hline \multirow{3}{*}{48} & Giriş & \multirow{3}{*}{ Krom } & Uygun & Uygun & Uygun & Uygun & 7,6 & 160 & 1,4 \\
\hline & Çık1ş & & Uygun & Uygun & Uygun & Uygun & 7,6 & 160 & 1,4 \\
\hline & 1. Kat & & Uygun & Uygun & Uygun & Uygun & 7,6 & 160 & 1,4 \\
\hline \multirow{3}{*}{49} & Giriş & \multirow{3}{*}{ Beton } & Uygun & Uygun & Uygun & Uygun & 7,6 & 240 & 0 \\
\hline & Çıkış & & Uygun & Uygun & Uygun & Uygun & 7,6 & 240 & 0 \\
\hline & 1. Kat & & Uygun & Uygun & Uygun & Uygun & 7,6 & 240 & 0 \\
\hline \multirow{3}{*}{50} & Giriş & \multirow{3}{*}{ Saç Depo } & Uygun & Uygun & Uygun & Uygun & 7,4 & 230 & 0 \\
\hline & Çıkış & & Uygun & Uygun & Uygun & Uygun & 7,4 & 230 & 0 \\
\hline & 1. Kat & & Uygun & Uygun & Uygun & Uygun & 7,4 & 230 & 0 \\
\hline \multirow{3}{*}{51} & Giriş & & Uygun & Uygun & Uygun & Uygun & 7,4 & 240 & 0 \\
\hline & Çıkış & Fayans & Uygun & Uygun & Uygun & Uygun & 7,4 & 240 & 0 \\
\hline & 1. Kat & & Uygun & Uygun & Uygun & Uygun & 7,4 & 240 & 0 \\
\hline & Giriş & & Uygun & Uygun & Uygun & Uygun & 7,4 & 180 & 0 \\
\hline 52 & Çıkış & Beton & Uygun & Uygun & Uygun & Uygun & 7,4 & 180 & 0 \\
\hline & 1. Kat & & Uygun & Uygun & Uygun & Uygun & 7,4 & 180 & 0 \\
\hline & Giriş & & Uygun & Uygun & Uygun & Uygun & 7,3 & 220 & 0 \\
\hline 53 & Çıkış & Fayans & Uygun & Uygun & Uygun & Uygun & 7,3 & 220 & 0 \\
\hline & 1. Kat & & Uygun & Uygun & Uygun & Uygun & 7,3 & 220 & 0 \\
\hline
\end{tabular}

* Uygun: 17.02.2005 Tarih 25730 sayılı resmi gazetede yayınlanan yönetmelikte belirtilen değerler arasında bulunmuştur.
Alınan su numunelerinde 2 istisnai örnek dışında renk, tat, bulanıklılık ve koku problemi de bulunmamaktadır. Yapılan araştırmalar, içme suyunda koku ve tat oluşturan belli başlı 
sebeplerden birincisinin algler, ikincisinin ise bitki örtüsünün çürüyüp ayrışması olduğunu göstermiştir [8].

Alınan su numunelerinde, $\mathrm{pH}$ düzeyleri incelendiğinde şebeke suyunun 6,9-8,4 değerleri arasında ve ortalama 7,4 değerinde olduğu ölçülmüştür. (Çizelge 1). Şebeke suyu örneklerinde ölçülen bu değerler "İnsani Tüketim Amaçlı Sular Hakkındaki Yönetmeliğe uygun olarak, 6,5-9,5 pH aralığında yer almaktadır.

\subsection{Bakteriyolojik Bulgular}

İnsani Tüketim Amaçlı Sular Hakkında Yönetmeliğine göre içme - kullanma sularında Enterekok, Total Koliform, E. coli varlığı kabul edilemez olup 100 mililitre su örneği için toplam koloni sayısı (cfu) 0 (sıfır)'1 geçmemelidir. $37{ }^{\circ} \mathrm{C}$ 'de koloni sayımı ise 100 mililitre örnek için maksimum 20 cfu olmalidir.

E. coli insan ve sıcakkanlı hayvanların bağırsak florasında bulunur. Numunelerin $E$. coli yönünden analizi sularda fekal kirliliğin olup olmadığının tespiti için yapılmaktadır. Koliform bakteriler bağırsakta doğal olarak bulunabileceği gibi toprak ve su da da bulunabilmektedir. Çalışmamızda koliform bakterilere bakmamızdaki amacimız depolamada veya dağıtım aşamalarında herhangi bir sorun olup olmadığını belirlemek içindir. İçme ve kullanma sularında koliform grup bakteri bulunması istenmez. Suda bu gruba ait bakterilerin tespiti, bizlere arıtma işleminin yetersiz olduğunun ya da arıtma sonrası dağıtım hatlarında meydana gelen bir kontaminasyonu düşündürür. $37{ }^{\circ} \mathrm{C}$ 'de toplam koloni sayımı $1 \mathrm{ml}$ sudaki tüm canlı mikroorganizmaların sayılması demektir. Bu test dağıtım sistemlerinin temizliğine ve suyun kalitesine ilişkin bilgiler verir. İçme sularında enterokok tespiti ise bizlere özellikle dişk1 kaynaklı bir kirliliğin göstergesi olduğunu gösterir ve bu gruba ait bakteriler, olumsuz koşullara ve klor gibi dezenfektanlara karşı E. coli ile kıyasla çok daha fazla direnç gösterdikleri bilinmektedir. Analiz sonuçlarımıza göre yer yer şebeke suyunda ve yer yer depodan kaynaklanan veya hidroforla 1 . kat arasındaki borulardan kaynaklanan uygunsuz/aykırı sonuçlar tespit edilmiştir (Çizelge 2). Aykırılık tespit edilen su örneklerinde, aykırı çıkmasının sebepleri arasında apartman içi su yapılarından kaynaklı bulaşıklar, örneğin depo, hidrofor ve borulardan kaynaklanan kirlilikten dolayı ya da dağıtım sistemindeki borulardan kaynaklanan sızıntılardan dolayı kirlilik etmenine rastlanılmıştır. Şehir şebeke suyunun dağıtım sistemlerindeki borularda oluşabilecek herhangi bir problemde (çatlak, sızıntı, boruların delinmesi) bu mikroorganizmaların çoğalmasına sebebiyet verecektir. Örneğin borulardaki negatif basınçtan doğabilecek sızıntılar ve/veya eskiyen borularda biyofilm oluşturan mikroorganizmaların varlığı da giriş sularında kontaminasyona sebebiyet vermektedir. Gene aynı şekilde hayvan ve insan dışkılarının ve dolayısıyla bu dışkılardaki hastalık yapıcı mikroorganizmalarında bir şekilde suya karıştığı durumlarda da bu mikroorganizmalara rastlanılır. Depo suyunun şebeke suyu olarak kullanıldığı binalarda dezenfeksiyon, temizlik işlemlerinin yeter miktarda yapılmadığı yerlerde de hastalık yapıcı mikroorganizmaların çoğaldığı görülmektedir.

Analizi yapilan beton depolardan 6 tanesinde total koliform bakteri analizinde uygunsuzluk tespit edilmiştir. $\mathrm{Bu}$ uygunsuzluğun 2 tanesi 1. kattan alınan örneklerde, 4 tanesi ise depo çıkışında tespit edilmiştir. $37{ }^{\circ} \mathrm{C}$ 'de koloni sayımında ise 8 tane numunede depo çıkışta, 1 tanesi depo girişten alınan örneklerde uygunsuzluk saptanmıştır, 1. kattan alınan örnekte ise uygunsuzluk görülmemiştir. Fayans depolardan alınan su numunelerinde 1 tane örnekte 1. katta koliform bakteri uygunsuzluğu tespit edilmiştir. $37{ }^{\circ} \mathrm{C}$ 'de koloni sayımı analiz sonuçlarına göre 5 örnekte depo çıkışta ve 2 örnekte 1. katta uygunsuzluk tespit edilmiştir. Galvaniz depolarda ise 3 apartmanın depo çıkışında uygunsuzluk tespit edilmiştir. Depo girişte 1, depo çıkış ve 1 . katta da 5 apartmanda uygunsuzluk tespit edilmiştir. Krom depolardan alınan örneklerin depo girişte 2, depo çıkışta 1 ve 1 . katta 1 olmak üzere toplamda 4 apartmanda uygunsuzluk tespit edilmiştir. $37^{\circ} \mathrm{C}$ de koloni sayımında ise, depo çıkışta 5 ve 1 . katta 3 olmak üzere 5 uygunsuzluk tespit edilmiştir. 
Plastik depolarda ise herhangi bir uygunsuzluk tespit edilememiştir. Yalnızca bir apartmanın hem giriş hem de çıkışında total koliforma rastlanmıştır. Hiçbir örnekte enterokoka rastlanmamıştır.

Çizelge 2. Depo tiplerine göre bulunan toplam uygunsuzluk sayisı

\begin{tabular}{|c|c|c|c|c|c|}
\hline 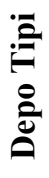 & 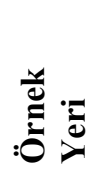 & 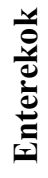 & 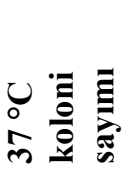 & 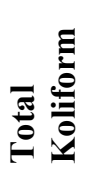 & $\underset{8}{\stackrel{5}{8}}$ \\
\hline \multirow{3}{*}{$\begin{array}{l}\text { Dี } \\
\text { D๊ }\end{array}$} & Giriş & 0 & 1 & 0 & 0 \\
\hline & Ç1k1ş & 1 & 8 & 4 & 0 \\
\hline & 1.Kat & 0 & 0 & 2 & 0 \\
\hline \multirow{3}{*}{ 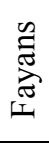 } & Giriş & 0 & 0 & 0 & 0 \\
\hline & Ç1k1ş & 0 & 5 & 0 & 0 \\
\hline & 1.Kat & 0 & 2 & 1 & 0 \\
\hline \multirow{3}{*}{ 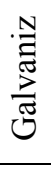 } & Giriş & 0 & 0 & 1 & 0 \\
\hline & Ç1k1ş & 0 & 5 & 2 & 0 \\
\hline & 1.Kat & 0 & 4 & 0 & 0 \\
\hline \multirow{3}{*}{ 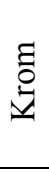 } & Giriş & 0 & 0 & 2 & 0 \\
\hline & Çık 1 ş & 0 & 5 & 2 & 0 \\
\hline & 1.Kat & 0 & 3 & 0 & 0 \\
\hline \multirow{3}{*}{ 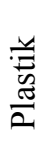 } & Giriş & 0 & 0 & 0 & 0 \\
\hline & Çı1k1ş & 0 & 0 & 0 & 0 \\
\hline & 1.Kat & 0 & 0 & 0 & 0 \\
\hline
\end{tabular}

\section{TARTIŞMA ve SONUÇ}

Suyun hayatın vazgeçilmezi olarak temiz ve sağlıklı olması gereklidir. İçme ve kullanma suları için hem dünyada hem de Türkiye'de farklı kurumlar tarafından standartlar belirlenmiştir. Sularda Koliform ve $E$. coli bulunması doğrudan ya da dolaylı yoldan fekal bir bulaşma olduğunun bir belirteci olarak kabul edilmekte olup, suda patojen bulunma olasılığını ve hijyen eksikliğini işaret etmektedir [5]. $\mathrm{Bu}$ sebeple sulardaki temizliğin kontrolü bu indikatör mikroorganizmaların sudaki varlıklarına bakılarak gerçekleştirilmekte ve diğer fiziksel ve kimyasal parametrelerle birleştirilerek su standartları oluşturulmaktadır. Dünya'da Dünya Sağlık Örgütü (WHO), ABD Çevre Korum Ajansı (EPA) ve Avrupa Birliği (EU) standartları yaygın olarak bilinirken, ülkemizde Türk Standartları Enstitüsü (TSE) ve T.C. Sağlık Bakanlığınca belirlenmiş olan İnsani Tüketim Amaçlı Sular Hakkında Yönetmelik kriterleri yaygın olarak kullanılmaktadır. Belirlenmiş standartların sağlanması için yerel yönetimler çeşitli çalışmalar yapmakta ve standardın sağlanması amaciyla düzenli aralıklarla ölçümler gerçekleştirmektedirler. Ancak merkezden temiz bir şekilde çıkan su evlere yolculuğu sırasında çeşitli kirlilik etmenlerine maruz kalmaktadır. Dönem dönem salgın hastalıklara sebep olan bu kirli suların temiz kalmalarının sağlanması, meydana gelebilecek hastalık ve ölümlerin önüne geçilmesi için büyük önem arz etmektedir. İçme suları hakkında literatürde de birçok çalışma bulmak mümkündür.

Rıfaat ve arkadaşları [9]'nın İstanbul İli ve çevresinde yaptıkları çalışmada alınan çeşme suyu örneklerinin \%12,2'sinde total koliform, fekal koliform ve $E$. coli bakterilerine rastlanmıştır. Depo sularından alınan örneklerin ise $\% 41,6$ total koliform, \%33,3 fekal koliform ve E. coli barındırdığ 1 gösterilmiştir. Avcı ve arkadaşları [10] Tokat İli'nde yaptıkları çalışmada alınan 2495 içme suyu örneğinin \%12,7'sinin koliform bakteri ile bulaşık olduğunu bulmuşlardır. Benzer şekilde, Akyüz ve Arslan [11] Konya ilinde yaptıkları çalışmada örneklerin \%12,76'sında total koliform ve $\% 2,65 E$. coli'ye rastlamışlardır. Muş ve Çetinkaya [5] tarafindan Bursa İli'nde 119 şebeke ve 81 artezyen kuyu suyu olmak üzere toplam 200 adet su örneğini mikrobiyolojik açıdan incelemiştir. Yapılan analizler sonucunda şebeke sularında sirasiyla $E$. coli ve Enterekok kontaminasyonu \%2,5, koliform ise \%12,6 olarak bulunmuştur. Analizini yaptıkları numunelerin \%3,5'inin yönetmelik kriterlerini karşılamadığı göstermişlerdir.

Adana'nın en büyük ilçesi olan Seyhan ilçesinde yapmış olduğumuz çalışma sonunda, depo girişinden, yani şebekeden alınmış olan su örneklerinde $\% 0,63$ oranında total koloni sayımında, \%1,89 oranında ise total koliform 
bakteri, $\% 0$ E. coli uygunsuzluğuna rastlanmıştır. $\mathrm{Bu}$ durumun ana şebekeden gelen suyun temizlenmemesinden ziyade, taşıma sırasında isale hatlarında meydana gelen kirlenmelerden kaynaklandığı düşünülmektedir. Çıkış sularında ise $\% 0,63$ enterekok, $\% 14,5$ total koloni sayımı, $\% 5$ total koliform ve $\% 0$ E. coli bakteri tespit edilmiştir. Depo sularına bakıldığında çalışmamızdaki değerlerin Rıfaat ve arkadaşlarının çalışmasından daha düşük olduğu görülmektedir. Yine koliform ve E. coli parametrelerinde tespit edilmiş değerlerin bazı [9-11] çalışmalarından düşük olduğu görülmektedir.

Depoya giren ve depodan çıkan sulardaki uygunsuzluk oranına bakıldığında suyun depoda kirlendiği sonucuna varılmaktadır. En fazla sayıda uygunsuzluk $(\% 80)$ beton türündeki depolarda gözlenmiştir. En düşük oran ise plastik $(\% 0)$ ve fayans (\%42) türündeki depolarda görülmüştür ancak burada plastik depo sayısı çeşitliliğinin olmadığı, örnek hacminin bir depo ile sinırlı olduğu göz önünde bulundurulmalıdır.

Su deposu materyali dışında su sağlığını etkileyen birçok faktör mevcuttur. Sicaklık içme ve kullanma amaçlı suların sağlığı konusunda önemli bir etkenlerden biridir. Sicaklığın mikroorganizmaların çoğalmasını arttırıcı etkisi olduğu çeşitli çalışmalarda bildirilmiştir $[10,12]$.

Su depolarının direk güneş ışığı almayacak şekilde yerleştirilmesi suyun hem mikrobiyolojik hem de fizikokimyasal özelliklerinin korunması açısından önemli ve gereklidir. Bunun yanında, şebekeden arıtılarak gelen içme ve kullanma suyunun temiz ve sağlıklı koşullarda depolanması da suyun kalitesi için gereklidir [13]. Bunun için su depoları yönetmelikte belirtilmiş olan sıklıkta dezenfekte edilmelidir. Aydın ve arkadaşları [7] Adana ilinde yapmış oldukları çalışmada su depolarının temizlik sıklığı konusunda halkın bilinçliliği konusunda anlamlı bir farklılık bulmuşlardır. Ayrıca Schafer ve Mihelcic [14] yaptıkları çalışmada yılda üç ve daha fazla temizlenen su depolarında daha az temizlenenlere göre, daha az sayıda $E$. coli ve turbiditeye rastlandığını belirtmişlerdir.
Depo şekli ve ortamı da suyun sağlığına direk etki etmektedir. Su deposu seçiminde, temizliğin ulaşmasını engelleyecek karesel biçimlerinden ziyade her yere eşit erişime izin verecek, kolay temizlenebilir bir materyal ile kaplanmış köşeleri yuvarlak tasarımlar tercih edilmelidir. Ayrıca depoların mutlak koruma sahaları olması gereklidir [13]. Örnek alımı esnasında özellikle beton depolarda herhangi bir koruma sahasının olmadığ1, üst bölgelerinin açık olduğu görülmüştür. $\mathrm{Bu}$ açıklık yabancı maddelerin (böcekler, toz, kuş tüyü vb.) suya ulaşmasına yol açmakta ve kontaminasyona sebebiyet vermektedir.

Yapılan çalışma sonunda, su sağlığı ve temizliğinin korunması konusunda; suyun halka sağlıkla ulaştırılmasının yeterli olmadığı, suların depolandığ 1 su depolarının bu konuda kritik öneme sahip olduğu görülmüştür.

Analiz sonuçlarımız her ne kadar kısıtlı bir alanda yapılsa da elde edilen veriler Adana şehir şebeke suyunun yüksek oranda içilebilir olduğunu göstermekle birlikte depo temizliğinin bu içilebilirlik ile doğrudan ilgili olduğunu göstermiştir. Depo dezenfeksiyonları düzenli yapılmalı, eskiyen, çatlayan, korozyana uğrayan depolar mutlaka yenilenmelidir. Yerel yönetimler bu konuda insiyatif alarak depolar ve içlerindeki suların kontrollerini sağlamak ve kirlilik düzeylerini izlemek üzere adımlar atmalı gerekli yerlerde önlemler almalıdırlar.

\section{TEŞEKKÜR}

Bu çalışma Çukurova Kalkınma Ajansı tarafından desteklenmiştir (TR62/14/DFD/0025).

\section{KAYNAKLAR}

1. Güler, Ç., Çobanoğlu, Z., 2006. Su kirliliği. Halk Sağlığı Temel Bilgiler Kitabında Hacettepe Üniversitesi Yayınlar1. 521-37.

2. www.isu.gov.tr, Erişim tarihi: 20.06.2016.

3. Gorchev, H.G., Ozolins, G., 2011. WHO Guidelines for Drinking-water Quality. WHO Chron, 38(3), 104-8. 
4. Forstinus, N.O., Ikechukwu, N.E., Emenike, M.P., Christiana, A.O., 2016. Water and waterborne diseases: A review. International Journal of Tropical Diseases and Health, 12 (4), 1-14.

5. Muş, E.T., Çetinkaya, F., 2017. Bursa'da İçme ve Kullanma Sularında İndikatör ve Bazı Patojen Bakterilerin Varlığının Araştırılması. Toprak Su Dergisi, 6(1), 1-6.

6. Novotny, V., Olem, H., 1994. Water Quality: Prevention, Identification, and Management of Diffuse Pollution.

7. Aydin, R., Atakav, Y., Ceylan, S.. 2016. An Analysis of Awareness and Consciousness of Public on the Indoor Water System in Apartment Building in Terms of Accessing to Clean Water, 31(October), 251-257.

8. Eroğlu, V., 1995. Su Tasfi yesi, İTÜ Yayınları, İstanbul, 314

9. Rifaat, E.A., Tekiner, İ.H., Özpınar, H., 2014. Halk Sağlığı Açısından İçme ve Kullanma Sularında Koliform ve Fekal Koliform Bakterilerin Varlıklarının Klasik ve MASS Spektrometresi Yöntemleriyle İncelenmesi. Electronic Journal of Food Technologies, 9(2), 20-32.

10. Avcı, S., Bakıcı, Z., Erandaç, M., 2005. Tokat İlindeki İçme Sularının Koliform Bakteriler Yönünden Araştırılması, 107-112.

11. Akyüz, T., Arslan, E., 2016. Bozkır (Konya, Türkiye)'in İçme Sularinda Fekal Kirlilik İndikatörü Bakterilerin Tespiti.

12. Kıvanç, M., Kunduhoğlu, B., Atik, S., Malkoçoğlu, B., 1996. Eskişehir İçme ve Kullanma Sularının Bakteriyolojik Kirliliği. Ekoloji, 19, 19-21.

13. Acehan, G., 2007. İçme Sularının Mikrobiyolojik Kirlenme Potansiyelinin İncelenmesi.

14. Schafer, C.A., Mihelcic, J.R., 2012. Effect of Storage Tank Material and Maintenance on Household Water Quality. American Water Works Association, 104(9), E521-E529. 
